\title{
UTILIZATION OF MOODLE WEB SERVICE BASED SYSTEM TO SYSTEM WITH SIAKAD AND SSO UNS
}

\author{
Ristu Saptono ${ }_{1,3)}^{(1)}$, Meiyanto Eko Sulistyo ${ }^{(2)}$, Joko Susilo(3) \\ ${ }^{1,3)}$ Program Studi Informatika \\ Fakultas Matematika dan IImu Pengetahuan Alam \\ Universitas Sebelas Maret, Surakarta \\ ${ }^{2)}$ Program Studi Teknik Elektro \\ Fakultas Teknik \\ Universitas Sebelas Maret, Surakarta \\ ristu.saptono@staff.uns.ac.id ${ }^{(1)}$, mekosulistyo@staff.uns.ac.id ${ }^{(2)}$, jokosusilo@student.uns.ac.id ${ }^{(3)}$
}

\begin{abstract}
The development of information technology in education allows for integration between systems so every system can be optimized. Elearning, SIAKAD, and SSO UNS are education system in UNS (Universitas Sebelas Maret) but they are not integrated yet. Course data for elearning is still manual and SSO which can not be used to log into SIAKAD. In this study the integration of elearning, SIAKAD, and SSO utilizing REST web service and exchange data using JSON. As a result, the integration of additional system must use a bridge application as a customizer data between elearning and SIAKAD. While the results of the testing to include one course, 40 lecturers, and 40 students, including automatically enroll is 60.22 seconds, while the time required for unenroll lecturers and students is 2:13 seconds. To enroll course, lecturers and students when there are previously data was 28.5 seconds.
\end{abstract}

Keywords: Elearning, JSON, SIAKAD, SSO, Web Service

\begin{abstract}
Abstrak
Perkembangan teknologi informasi dalam pendidikan memungkinkan untuk integrasi antar sistem sehingga setiap sistem dapat dioptimalkan. Elearning, SIAKAD, dan SSO UNS yang sistem pendidikan di UNS (Universitas Sebelas Maret) tetapi mereka belum terintegrasi. Data mata kuliah untuk elearning masih manual dan SSO yang tidak dapat digunakan untuk login ke SIAKAD. Dalam penelitian ini integrasi elearning, SIAKAD, dan SSO memanfaatkan REST web service dan pertukaran data menggunakan JSON. Akibatnya, integrasi sistem tambahan harus menggunakan aplikasi bridge sebagai data penyesuai antara elearning dan SIAKAD. Sedangkan hasil pengujian untuk memasukkan satu mata kuliah, 40 dosen dan 40 mahasiswa, termasuk secara otomatis mendaftarkan diri adalah 60,22 detik, sedangkan waktu yang dibutuhkan untuk dosen dan mahasiswa membatalkan pendaftaran 2,13 detik. Untuk mendaftarkan mata kuliah, dosen, dan mahasiswa ketika ada data sebelumnya adalah 28,5 detik.
\end{abstract}

Kata Kunci: Elearning, JSON, SIAKAD, SSO, Web Service

\section{PENDAHULUAN}

Universitas Sebelas Maret (UNS) mempunyai visi menjadi pusat pengembangan ilmu, teknologi, dan seni yang unggul di tingkat internasional dengan berlandaskan pada nilai-nilai luhur budaya nasional [1]. Salah satu penerapan teknologi adalah dengan menggunakan elearning sebagai komplementer proses belajar mengajar. Elearning merupakan suatu jenis belajar mengajar yang memungkinkan tersampaikannya bahan ajar ke siswa dengan menggunakan media internet, intranet, atau media jaringan komputer lain [2].

Elearning yang dipakai oleh Universitas Sebelas Maret adalah adalah MOODLE (Modular Object-Oriented Dynamic Learning Environment) [3]. Menurut penelitian salah satunya [4] serta [5] dilihat dari beberapa kategori dan fitur yang dimiliki seperti Usability, Adaptation, Course 
Management, dan lain-lain, MOODLE adalah yang terbaik. Selain elearning yang memakai MOODLE, aplikasi lain yang mendukung sistem belajar mengajar adalah Sistem Informasi Akademik (SIAKAD) UNS yang digunakan untuk manajemen data civitas akademik. Sedangkan, Single Sign On (SSO) digunakan untuk pemusatan data diri civitas akademik, email, dan akun untuk login ke hotspot.

Masalah yang dihadapi dari hadirnya beberapa aplikasi tersebut, adalah setiap kali masuk ke semester baru, dosen akan membuat course (kelas), melakukan enroll (membuka kelas), dan unenroll (menutup kelas) manual terhadap mahasiswa yang ada. Sedangkan mahasiswa baru akan mendaftar elearning secara manual. Hal ini terasa kurang maksimal penggunaanya karena data mata kuliah (course) di elearning bisa diambil dari data mata kuliah yang ada di SIAKAD, sedangkan data mahasiswa dan dosen di elearning bisa diambil dari SSO sebagaimana terlihat pada gambar 1.

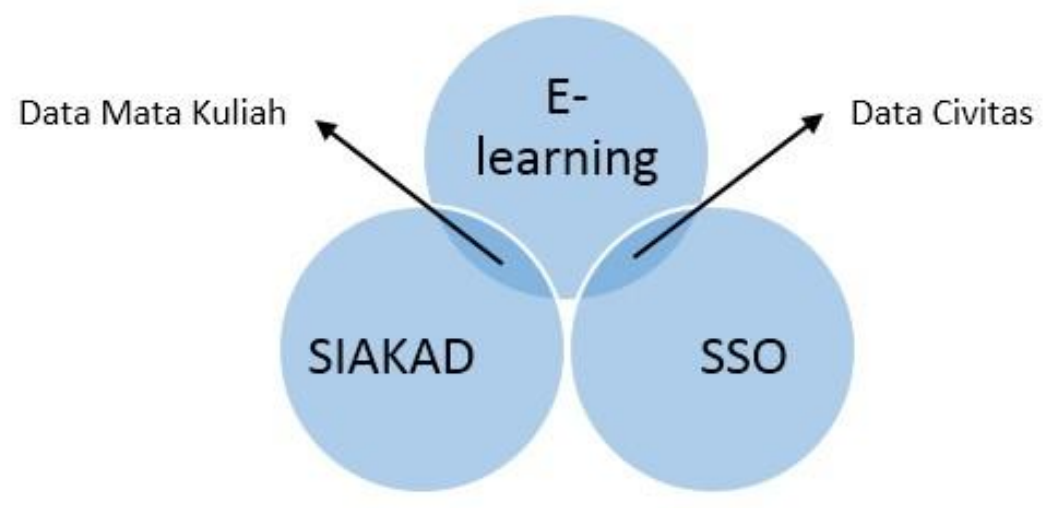

Gambar 1. Hubungan data antar sistem

Dengan mengintegrasikan ketiga sistem tersebut, maka pembuatan course (kelas), pembuatan akun elearning, enroll course (membuka kelas), dan unenroll course (menutup kelas) akan bisa dilakukan secara otomatis. Hal ini tentu akan menjadikan dosen dan mahasiswa lebih fokus pada proses belajar mengajar di kelas dan tidak perlu melakukan pembuatan course (kelas) atau pendaftaran di elearning. Integrasi ini bisa dilakukan karena MOODLE menyediakan fitur atau modul web service.

Web service adalah sebuah sistem software yang didesain untuk mendukung interoperabilitas interaksi mesin ke mesin melalui sebuah jaringan [6]. MOODLE versi 2.9 mendukung empat engine web service, yaitu AMF, SOAP, REST, dan XML-RPC. Pemanfaatan web service MOODLE sebelumnya oleh Bayu Wicaksono adalah Model Pemanfaatan Web Service Moodle Berbasis REST-JSON Secara Mobile Dengan Perancangan Native Client Berbasis Android [7]. Memanfaatkan web service moodle untuk membuat sebuah aplikasi android, yang bisa mengakses beberapa fungsi yang ada di moodle. Dari penelitian tersebut belum membahas mengenai pemanfaatan web service MOODLE yang dihubungkan dengan web service lain. Dalam hal ini adalah sistem SIAKAD dan SSO. Karena pada dasarnya web service moodle dibangun untuk bisa digunakan untuk system to system yang artinya bisa menghubungkan antara dua aplikasi.

Dibutuhkan sebuah aplikasi untuk menjembatani web service satu dengan web service lainnya. Pada penelitian ini, digunakan REST sebagai engine karena REST lebih powerfull dibanding dengan SOAP, dan untuk format pertukaran datanya menggunakan JSON karena lebih ringan jika digunakan untuk data yang isinya banyak [8]. Sedangkan metode yang dipakai adalah waterfall karena sangat cocok dengan project yang requirement-nya sudah pasti.

Dengan adanya integrasi antara elearning (MOODLE), SIAKAD dan SSO UNS maka akan di dapat elearning yang berjalan secara seamlessly, artinya pembuatan course (kelas), pembuatan akun elearning, enroll course (membuka kelas), dan unenroll course (menutup kelas) akan bisa dilakukan secara otomatis, sehingga proses belajar mengajar akan lebih optimal. 


\section{DASAR TEORI}

\subsection{Elearning}

Elearning merupakan suatu jenis belajar mengajar yang memungkinkan tersampaikannya bahan ajar ke siswa dengan menggunakan media internet, intranet, atau media jaringan komputer yang lain [2]. Sesuai dengan namanya, arti elearning adalah sistem pembelajaran menggunakan media elektronik. Sistem pembelajaran ini mulai berkembang seiring perkembangan teknologi itu sendiri. Salah satu implementasinya dengan menggunakan LMS.

LMS atau singkatan dari Learning Management System adalah suatu perangkat lunak atau software untuk keperluan administrasi, dokumentasi, laporan sebuah kegiatan, kegiatan belajar mengajar dan kegiatan secara online (terhubung ke internet), elearning, dan materi-materi pelatihan. Dan semua itu dilakukan dengan online. [9].

Salah satu LMS yang paling popular adalah MOODLE. MOODLE atau singkatan dari Modular Object-Oriented Dynamic Learning Environment adalah sebuah paket aplikasi untuk elearning yang bersifat open source. Karena sifat open source inilah, maka pengguna MOODLE cepat berkembang dan memiliki andil dalam mengembangkan moodle itu sendiri. Caranya dengan pembuatan plugin atau module untuk MOODLE.

\subsection{Web Service}

Web service adalah sebuah sistem yang didesain untuk mendukung interaksi mesin dengan mesin yang melalui sebuah jaringan [10]. Dalam bahasa yang lebih mudah, web service adalah sebuah sistem yang dibuat untuk pertukaran data dengan sistem atau aplikasi lain. Arsitektur web service memiliki 4 model [11] yaitu sebagai berikut :

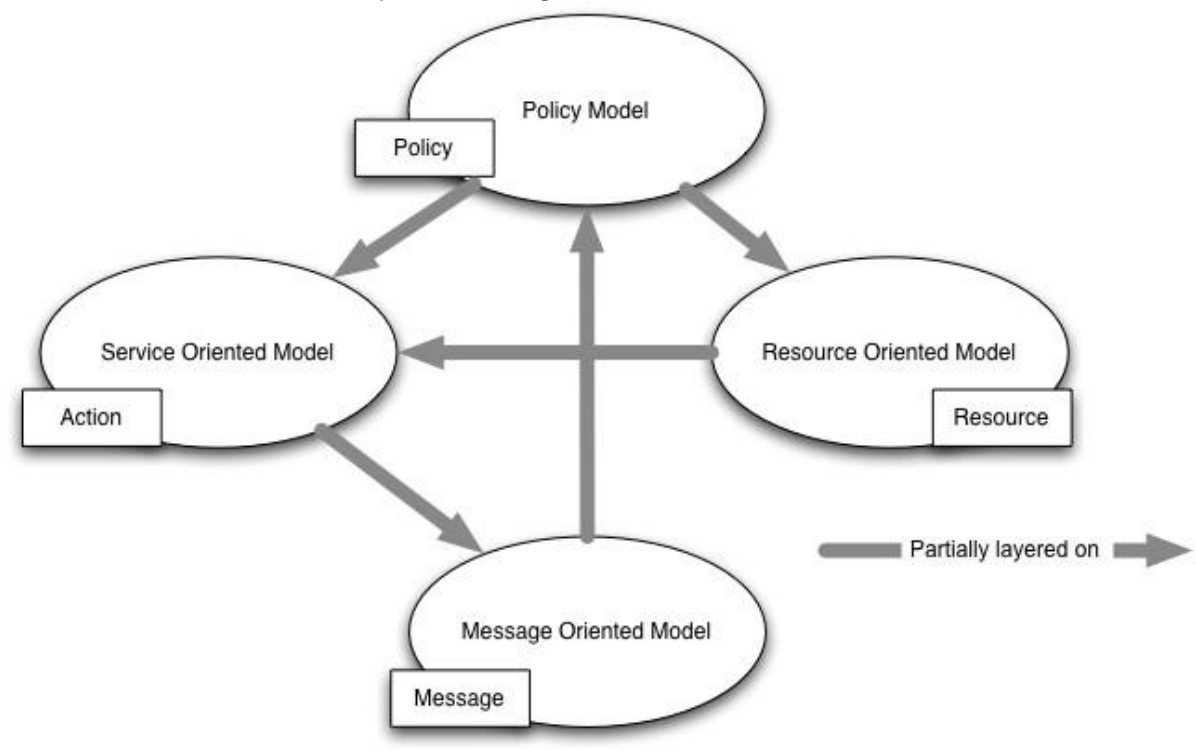

Gambar 2. Arsitektur Web Service [11]

1. Message Oriented Model

Fokus pada aspek arsitektur yang berhubungan dengan pesan dan prosesnya seperti struktur pesan, transportasi pesan dan yang lainnya.

2. Service Oriented Model

Fokus pada arsitektur yang berhubungan dengan servis dan aksi.

3. Resource Oriented Model

Fokus pada aspek yang berhubungan dengan resource. Resource adalah konsep paling fundamental dalam web service.

4. Policy Oriented Model

Fokus pada aspek arsitektur yang berhubungan dengan aturan, contohnya keamanan dan kualitas dari servis yang dihasilkan. 
Dari 4 model di atas, Service Oriented Model berkembang menjadi SOAP dan Resource Oriented Model berkembang menjadi REST. SOAP adalah sebuah protokol yang diusulkan oleh W3C untuk antarmuka web service dan digunakan untuk memanggil fungsi remote (XMLRPC), sedangkan REST adalah sebuah arsitektur metode komunikasi untuk sistem hypermedia terdistribusi, seperti World Wide Web yang diperkenalkan oleh Roy Fielding di tahun 2000 melalui disertasinya. REST memiliki karakteristik sebagai berikut [12]:

1. Menggunakan HTTP method secara eksplisit

2. Stateless

3. Memiliki struktur direktori URI

4. Pesan yang ditransfer dalam format XML, JSON, atau keduanya.

\subsection{Format Data}

Format data yang sering dipakai dalam web service adalah XML dan JSON.

1. $X M L$

XML (Extensible Markup Language) adalah sebuah format data yang berasal dari SGML (ISO 8879). Awalnya di desain untuk memenuhi kebutuhan penerbitan elektronik dalam skala besar. Kemudian berkembang dan memiliki peranan penting dalam pertukaran data di di web [13]. Contoh penggunaan XML untuk mendeklarasikan data adalah sebagai berikut:

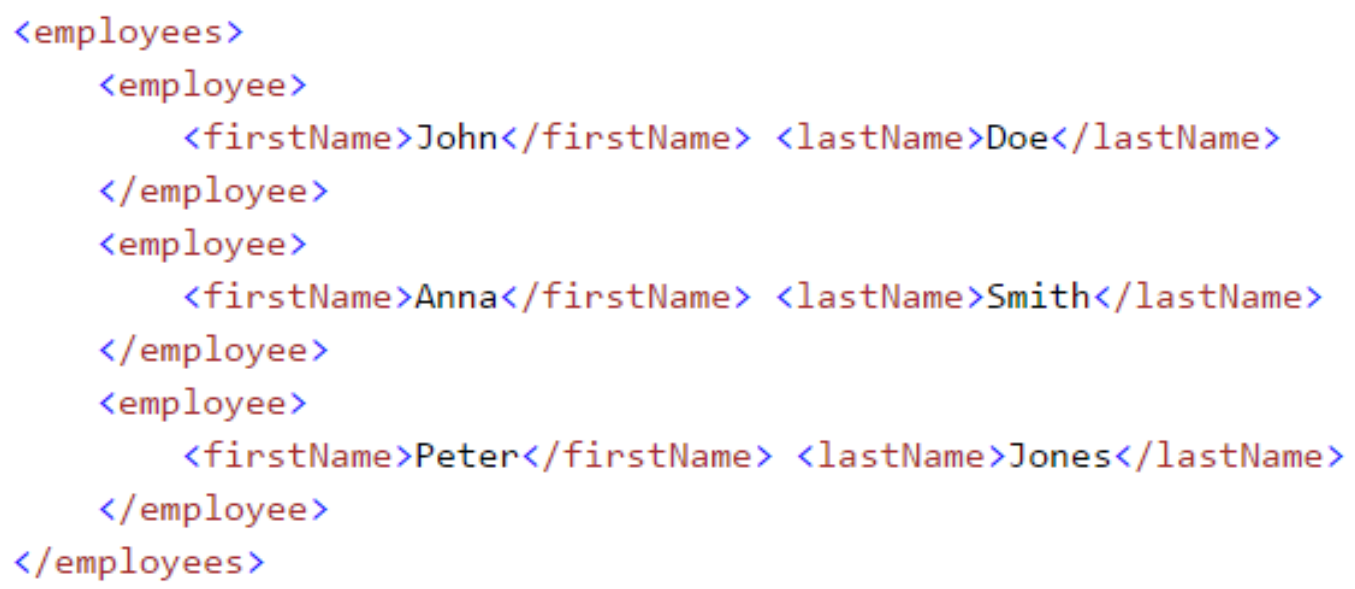

Gambar 3. Contoh Penggunaan XML [14]

\section{JSON}

JSON (JavaScript Object Notation) adalah format pertukaran data yang ringan, mudah dibaca dan ditulis oleh manusia, serta mudah diterjemahkan dan dibuat (generate) oleh komputer. Format ini dibuat berdasarkan bagian dari Bahasa Pemrograman JavaScript, Standar ECMA-262 Edisi ke-3 - Desember 1999. JSON merupakan format teks yang tidak bergantung pada bahasa pemprograman apapun karena menggunakan gaya bahasa yang umum digunakan oleh programmer keluarga $\mathrm{C}$ termasuk $\mathrm{C}, \mathrm{C}++, \mathrm{C \#}$, Java, JavaScript, Perl, Python, dan lain-lain. Oleh karena sifat-sifat tersebut, menjadikan JSON ideal sebagai bahasa pertukaran-data [15]. JSON terbuat dari dua struktur [15]:

1. Kumpulan pasangan nama/nilai. Pada beberapa bahasa, hal ini dinyatakan sebagai objek (object), rekaman (record), struktur (struct), kamus (dictionary), tabel hash (hash table), daftar berkunci (keyed list), atau associative array.

2. Daftar nilai terurutkan (an ordered list of values). Pada kebanyakan bahasa, hal ini dinyatakan sebagai larik (array), vektor (vector), daftar (list), atau urutan (sequence).

Contoh penggunaan JSON untuk mendeklarasikan data adalah sebagai berikut : 


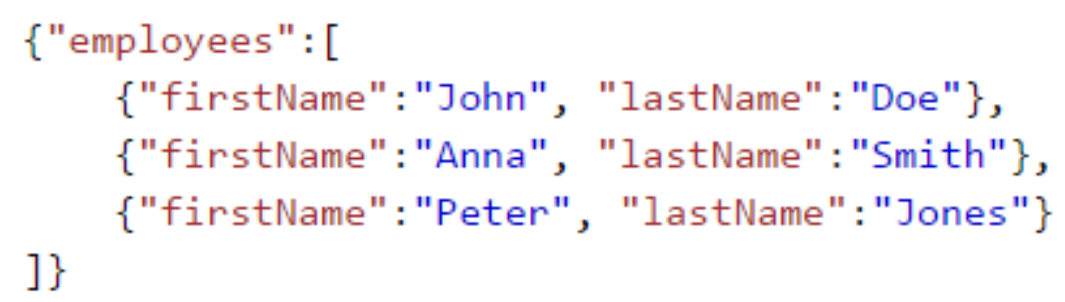

Gambar 4. Contoh Penggunaan JSON [14]

\subsection{SSO}

Single Sign-On (SSO) adalah sebuah sesi atau proses autentikasi yang memperbolehkan seorang user menggunakan satu username dan password untuk mengakses beberapa aplikasi [16]. Beberapa keuntungan penggunaan SSO adalah sebagai berikut

1. User tidak perlu mengingat banyak username dan password.

2. Kemudahan pemrosesan data, karena data yang ada sudah terpusat

3. Tidak perlu membuat data pengguna yang sama di setiap aplikasi. Menghemat biaya untuk pemeliharaan akun.

\section{METODOLOGI}

Tahapan penelitian ini adalah sebagai berikut :

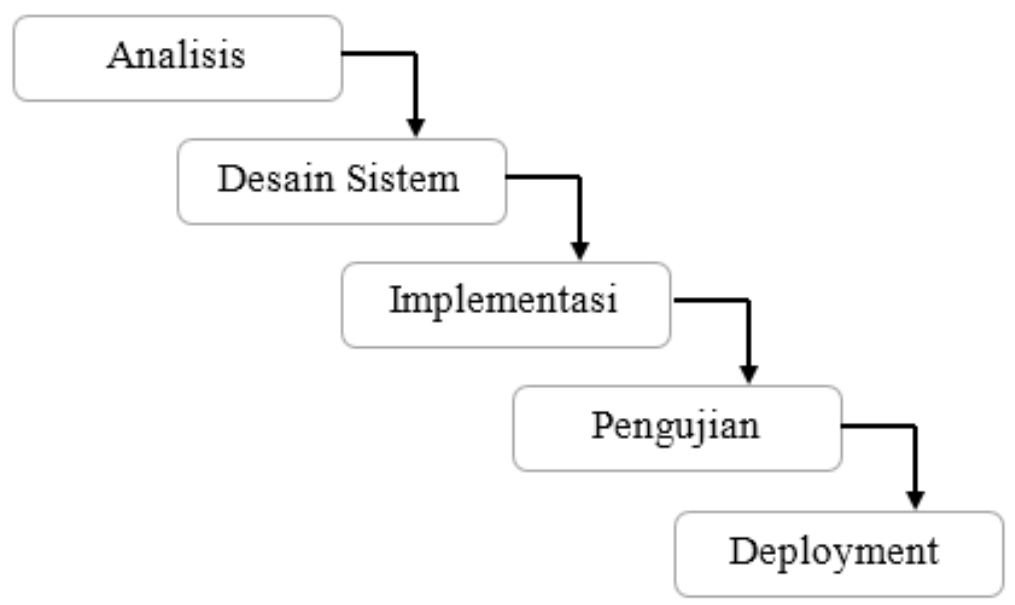

Gambar 5. Tahapan Penelitian

\subsection{Analisis}

Dalam proses analisis ini dilakukan identifikasi business case, selanjutnya menentukan requirement (kebutuhan sistem) yang akan digunakan dalam proses pembuatan aplikasi. Selain itu, juga dilakukan studi terhadap rencana aplikasi yang akan digunakan, menggunakan platform apa dan tools-nya apa saja.

\subsection{Desain Sistem}

Setelah mengetahui kebutuhan dan fitur yang akan dibuat dari proses analisis, maka selanjutnya pada desain sistem dilakukan perancangan sistem. Perancangan ini meliputi design UI (User Interface), data model, alur program dan rancangan sistem. Rancangan sistem nantinya akan dibuat berdasarkan diagram UML. 


\subsection{Implementasi}

Merupakan tahap menterjemahkan model atau desain yang telah ditetapkan pada proses analisis dan desain sistem ke dalam bahasa yang dimengerti komputer.

\subsection{Pengujian}

Setelah penyelesaian proses implementasi, selanjutnya dilakukan testing. Tahapan ini ialah tahapan di mana developer harus menguji kelayakan aplikasi apakah sesuai dengan yang diharapkan atau tidak. Proses testing dan debugging dibagi menjadi 2 macam. Pengujian yang pertama, black box testing, yaitu pengujian untuk mengetahui apakah semua fungsional sistem berjalan sesuai yang direncanakan atau tidak. Sedangkan, pengujian kedua adalah pengujian response time, yaitu pengujian untuk mengetahui berapa waktu yang dibutuhkan sistem untuk melakukan enroll dan unenroll.

\subsection{Deployment}

Ini merupakan tahap terakhir dalam model waterfall. Software yang sudah jadi dilakukan pemasangan atau dijalankan serta dilakukan pemeliharaan.

Pemeliharaan termasuk dalam memperbaiki kesalahan yang tidak ditemukan pada langkah sebelumnya.

\section{HASIL DAN PEMBAHASAN}

\subsection{Analisis}

Aplikasi yang akan dikembangkan adalah aplikasi penengah (Bridge App) antara elearning dan SIAKAD. Aplikasi ini akan dikelola oleh admin dengan cara mengisi jadwal kapan dilakukan enroll dan unenroll terhadap dosen dan mahasiswa. Kondisi awal dari semua sistem adalah elearning dan aplikasi berada dalam kondisi kosong hanya berisi data default. Admin akan menambahkan jadwal kapan dilakukan enroll dan unenroll tiap semester pada sistem. Enroll akan dilakukan setelah jadwal pengambilan mata kuliah di SIAKAD selesai. Karena data pengambilan mata kuliah digunakan untuk membuat course (kelas), user dosen, dan user mahasiswa di elearning. Setelah itu jadwal dimasukkan, sistem akan melakukan pencocokan jadwal setiap hari. Jika jadwal enroll sama dengan hari sekarang maka akan dilakukan proses enroll, begitu juga saat jadwal unenroll. Proses enroll adalah proses dimana aplikasi akan mengambil data dari SIAKAD berupa data mata kuliah, user dosen beserta mata kuliah yang diampu, dan mahasiswa beserta mata kuliah yang diambil untuk kemudian dimasukkan ke dalam elearning (MOODLE). Setelah proses pemasukan data tadi, kemudian dilakukan proses enroll atau proses memasukkan dosen dan mahasiswa ke dalam course (kelas) masingmasing. Sedangkan, proses unenroll adalah proses dimana course (kelas) akan ditutup sementara waktu sampai semester berikutnya, sehingga mahasiswa dan dosen tidak akan bisa lagi masuk ke dalam kelas.

\subsubsection{Kebutuhan Fungsional}

1. Sistem dapat menerima login dari admin.

2. Setelah login, admin dapat melihat daftar mata kuliah, mahasiswa dan dosen yang ada di MOODLE melalui sistem.

3. Setelah login, admin dapat melakukan proses pengelolaan jadwal running aplikasi, seperti menambahkan jadwal dan melihat jadwal.

4. Sistem dapat secara otomatis membuatkan akun untuk dosen dan mahasiswa berdasarkan NIP atau NIM. NIP atau NIM inilah yang nantinya dicocokkan dengan data SSO sehingga dosen dan mahasiswa bisa login elearning menggunakan SSO.

5. Sistem dapat melakukan proses enroll dosen dan mahasiswa terhadap kelas di elearning secara otomatis.

6. Dosen dan mahasiswa dapat melakukan login di elearning menggunakan SSO. 
7. Setelah login, mahasiswa dapat melihat data course (kelas) di elearning, sedangkan dosen dapat pula melakukan perubahan dari kelas yang dibimbing.

\subsubsection{Kebutuhan Non-Fungsional}

1. Sistem menyimpan data mata kuliah, mahasiswa dan dosen.

2. Sistem berjalan 24 jam perhari

3. Sistem melakukan pengecekan jadwal enroll dan unenroll setiap hari sekali

\subsection{Desain Sistem}

Arsitektur pengembangan sistem secara keseluruhan dapat dilihat pada gambar berikut:

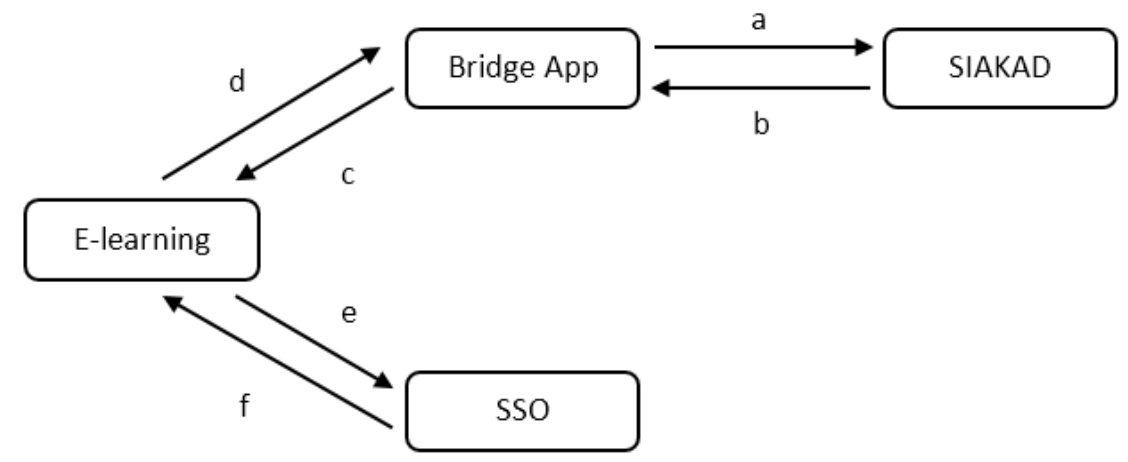

Gambar 6. Desain Aplikasi

Keterangan Gambar 6 :

a. Bridge App me-request data ke SIAKAD

b. Bridge App mendapat data dari SIAKAD

c. Data dari SIAKAD dikirim ke elearning

d. Elearning mengirim data kembalian berupa hasil eksekusi fungsi MOODLE

e. Elearning melakukan request login ke SSO

f. SSO mengirim data kembalian ke elearning

Setelah dilakukan studi terhadap data dan requirement yang dibutuhkan dalam aplikasi. Ada 3 sistem yang akan digunakan pada penelitian ini, yaitu Sistem Informasi Akadmik (SIAKAD), elearning (MOODLE), Single Sign On (SSO).

\subsubsection{SIAKAD}

SIAKAD yang digunakan bukanlah SIAKAD sungguhan. SIAKAD yang digunakan berupa web service dengan 3 fungsi yang akan mengembalikan data JSON tergantung dari fungsi yang dipanggil. Tabel 1 berikut berisi daftar fungsi API SIAKAD.

Tabel 1. Daftar fungsi API SIAKAD

\begin{tabular}{|ll|}
\hline Nama fungsi & Deskripsi \\
\hline getMata kuliah & Return JSON berisi daftar mata kuliah berupa nama panjang dan singkatan \\
\hline getDosen & Return JSON berisi daftar dosen beserta mata kuliah yang diampu \\
\hline getMahasiswa & Return JSON berisi daftar mahasiswa beserta mata kuliah yang diambil \\
\hline
\end{tabular}

\subsubsection{Elearning (MOODLE)}

Untuk menggunakan web service MOODLE, hal yang harus dilakukan adalah dengan login sebagai administrator kemudian menghidupkan fungsi web service. Setelah itu, hidupkan tipe web service REST. Dan lakukan generate key. Key ini yang akan digunakan di aplikasi. Dan kemudian web service MOODLE siap digunakan. Salah satu data yang dibutuhkan adalah tipe user MOODLE. Tipe user di MOODLE dibedakan menjadi beberapa kategori. Tipe user inilah 
yang nantinya digunakan untuk membedakan antara dosen dan mahasiswa. Tabel 2 berikut berisi daftar tipe user yang ada di MOODLE.

Tabel 2. Daftar tipe user dan level di elearning MOODLE

\begin{tabular}{|l|l|l|}
\hline No & Tipe User & Deskripsi \\
\hline 1 & Site administrator & Dapat 'melakukan apa saja' di website \\
\hline 2 & Manager & Role yang sedikit lebih sempit dibanding admin \\
\hline 3 & Course Creator & Dapat membuat kelas (course) \\
\hline 4 & Teacher & Dapat mengelola dan menambah konten ke kelas (course) \\
\hline 5 & Non-editing teacher & Dapat mengelola kelas (course), tapi tidak bisa mengedit \\
\hline 6 & Student & Dapat mengakses dan berpartisipasi di kelas \\
\hline
\end{tabular}

Data selanjutnya adalah daftar fungsi web service yang ada di MOODLE. Fungsi-fungsi inilah yang bisa diakses untuk melakukan perubahan di dalam aplikasi moodle melalui web service.

Setelah melakukan studi literatur dan analisa terhadap masalah yang ada, dipilih beberapa fungsi yang sesuai kebutuhan aplikasi. Dari daftar fungsi tersebut, fungsi yang dipakai dalam aplikasi ditunjukkan oleh tabel 3 sebagai berikut.

Tabel 3. Daftar fungsi web service moodle yang dipakai

\begin{tabular}{|l|}
\hline Nama Fungsi \\
\hline core_course_get_categories \\
\hline core_course_create_categories \\
\hline core_course_get_courses \\
\hline core_user_create_users \\
\hline core_course_create_courses \\
\hline enrol_manual_enrol_users \\
\hline
\end{tabular}

4.2.3. SSO

Untuk dapat menggunakan Single Sign On (SSO) Universitas Sebelas Maret, perlu ditambahkan plugin auth_saml ke dalam MOODLE. Selain itu di mesin yang sama harus terinstall SimpleSAMLphp. Setelah sistem yang lain siap, selanjutnya adalah daftar fungsi aplikasi. Tabel 4 merupakan daftar fungsi di Bridge App.

Tabel 4. Daftar fungsi bridge app

\begin{tabular}{|l|l|l|}
\hline Golongan & Nama fungsi & Deskripsi \\
\hline \multirow{4}{*}{ Course } & checkCourse & $\begin{array}{l}\text { Melakukan cek ke database apakah suatu course sudah di masukkan } \\
\text { ke elearning atau belum }\end{array}$ \\
\cline { 2 - 4 } & Send & Melakukan pemanggilan web service ke elearning \\
\cline { 2 - 4 } & saveCourse & Melakukan save data course ke database \\
\hline \multirow{4}{*}{ Dosen } & checkCourse & $\begin{array}{l}\text { Melakukan cek ke database apakah dosen dengan nama yang dicek } \\
\text { sudah di masukkan ke elearning atau belum }\end{array}$ \\
\cline { 2 - 4 } & Send & Melakukan pemanggilan web service ke elearning \\
\cline { 2 - 4 } & saveCourse & Melakukan save data dosen ke database \\
\hline \multirow{4}{*}{ Mahasiswa } & checkCourse & $\begin{array}{l}\text { Melakukan cek ke database apakah mahasiswa dengan nama yang } \\
\text { dicek sudah di masukkan ke elearning atau belum }\end{array}$ \\
\cline { 2 - 4 } & Send & Melakukan pemanggilan web service ke elearning \\
\cline { 2 - 4 } & saveCourse & Melakukan save data mahasiswa ke database \\
\hline
\end{tabular}


Use Case Glossary sebagai bagian dari perancangan aplikasi dapat dilihat di bawah ini.

Tabel 5. Use Case Glossary

\begin{tabular}{|l|l|l|}
\hline Kode & Use Case & Deskripsi \\
\hline UC-001 & Login & Dosen dan Mahasiswa login ke elearning \\
\hline UC-002 & Autentikasi & SSO member akses autentikasi ke elearning \\
\hline UC-003 & Input Jadwal & Admin mengelola jadwal \\
\hline UC-004 & Create Course & Sistem menambahkan course ke elearning \\
\hline UC-005 & Create Dosen & Sistem menambahkan dosen ke elearning \\
\hline UC-006 & Enroll Dosen & Sistem melakukan enroll dosen ke elearning \\
\hline UC-007 & Create Mahasiswa & Sistem menambahkan mahasiswa ke elearning \\
\hline UC-008 & Enroll Mahasiswa & Sistem melakukan enroll mahasiswa ke elearning \\
\hline
\end{tabular}

Use Case diagram dapat dilihat pada gambar berikut.
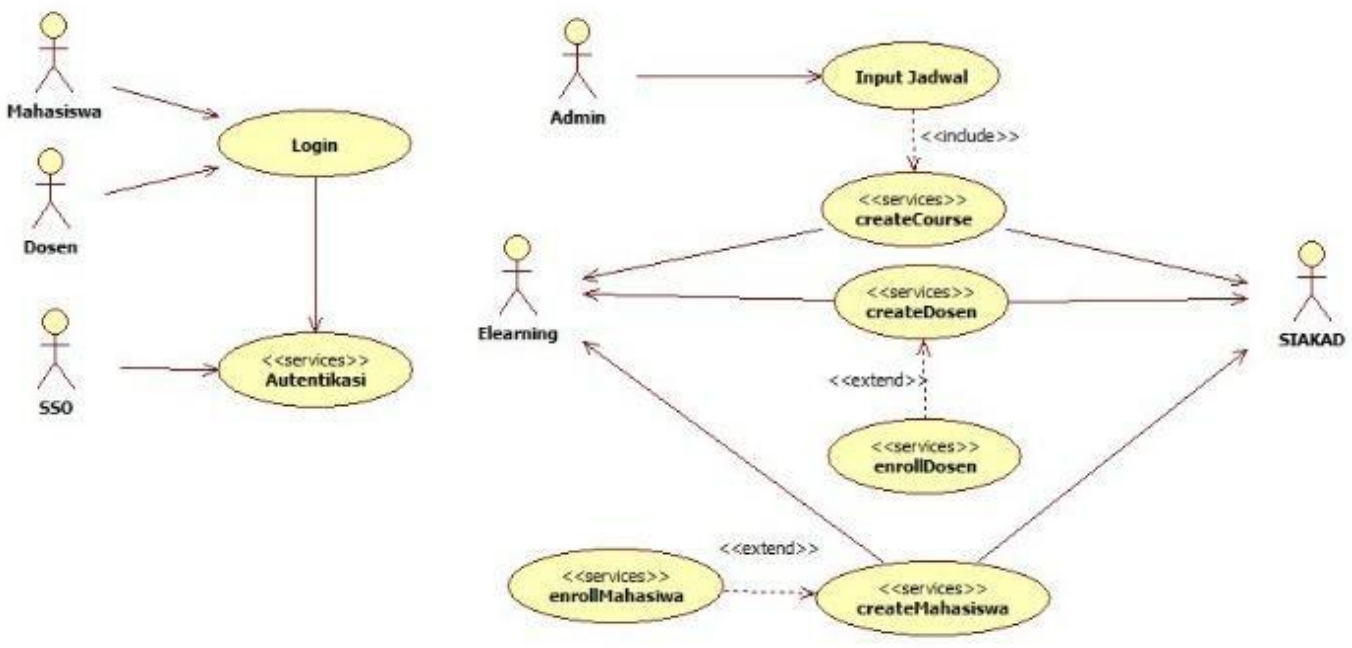

Gambar 7. Use Case Diagram

\subsection{Implementasi}

Hasil implementasi dari prototipe sistem yang menghubungkan SIAKAD dengan elearning adalah sebagai berikut :

1. Data JSON untuk fungsi getMataKuliah

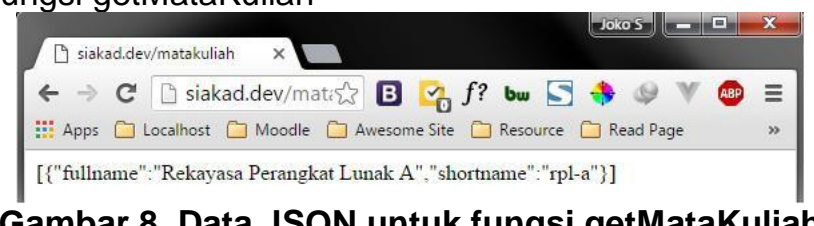

Gambar 8 diatas adalah JSON hasil request dari aplikasi ke SIAKAD untuk mata kuliah.

2. Data JSON untuk fungsi getDosen

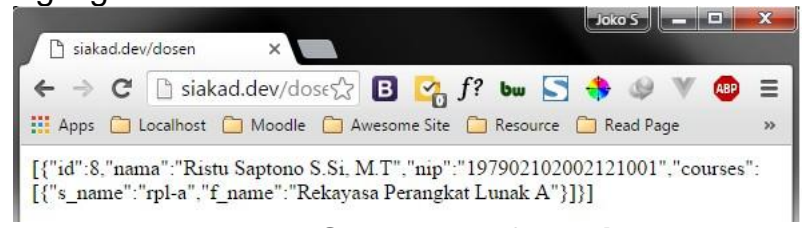

Gambar 9. Data JSON untuk fungsi getDosen 
Gambar 9 diatas adalah JSON hasil request dari aplikasi ke SIAKAD untuk mata kuliah.

3. Data JSON untuk fungsi getMahasiswa

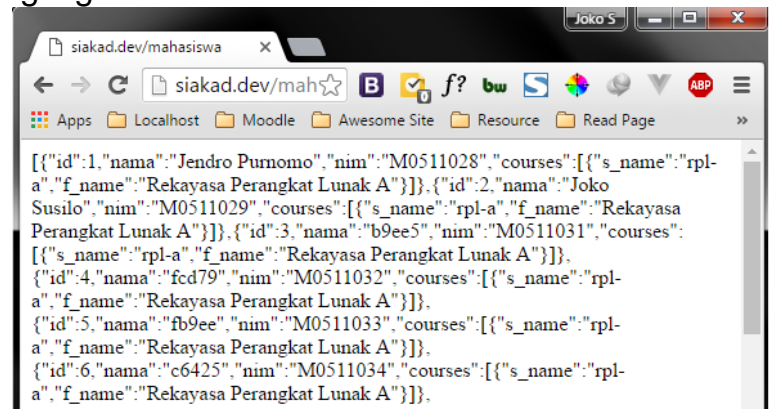

\section{Gambar 10. Data JSON untuk fungsi getMahasiswa}

Gambar 10 di atas adalah JSON hasil request dari aplikasi ke SIAKAD untuk mahasiswa.

4. Halaman Login Administrator

Sistem Manajemen Elearning

\section{Login Administrator}

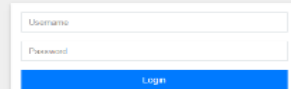

\section{Gambar 11. Tampilan Halaman Login Administrator}

Halaman ini digunakan administrator untuk login ke dalam sistem.

5. Halaman Home

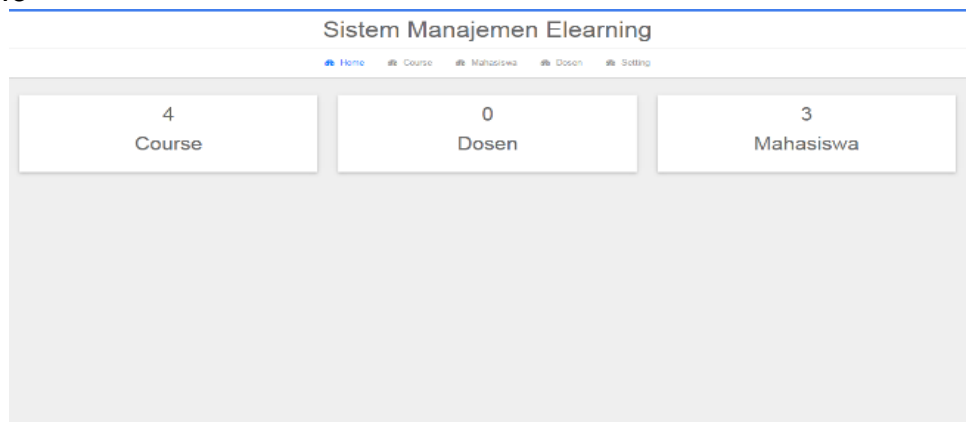

\section{Gambar 12. Tampilan Halaman Home}

Halaman home menyajikan jumlah course, dosen, dan mahasiswa yang ada di elearning, terlihat di gambar 12. 
6. Halaman Course

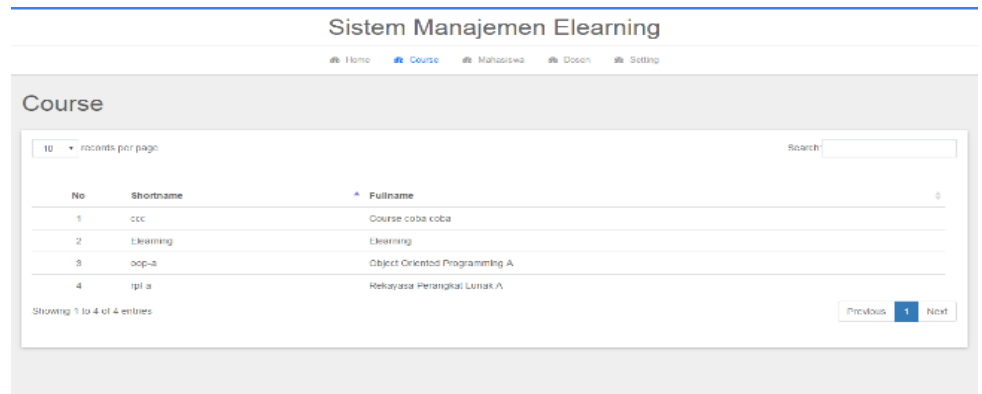

Gambar 13. Tampilan Halaman Course

Beralih ke halaman course yang berisi semua course yang ada di elearning. Data yang di simpan dari course adalah shortname dan fullname-nya. Tampilan data course dapat di lihat di gambar 13.

7. Halaman Dosen

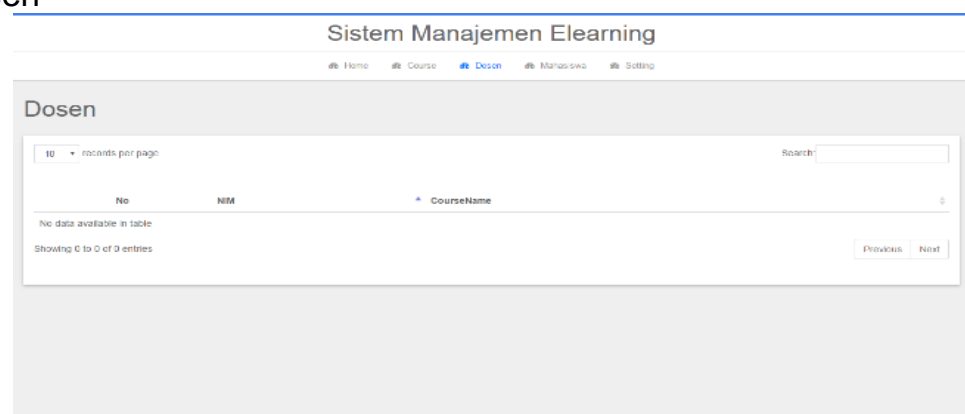

Gambar 14. Tampilan Halaman Dosen

Menu selanjutnya adalah dosen, yang berisi data semua dosen yang ada di elearning. Seperti course, datanya berbentuk tabel. Untuk field yang disimpan adalah NIM dan course yang diambil.

8. Halaman Mahasiswa

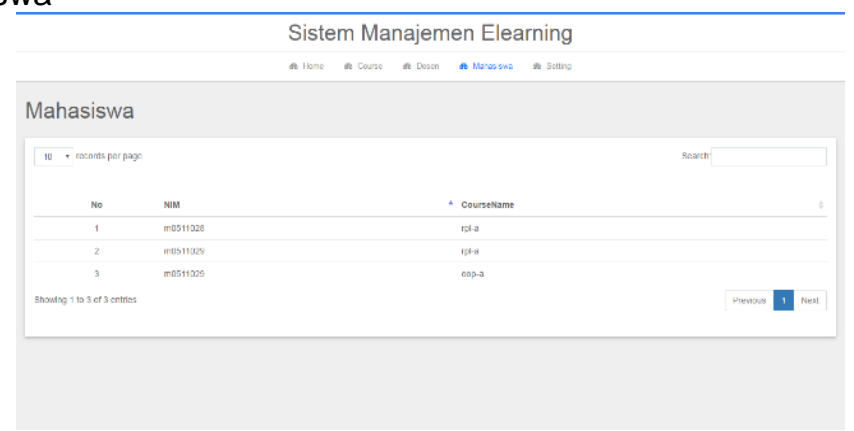

\section{Gambar 15. Tampilan Halaman Mahasiswa}

Kemudian, menu yang disebelahnya adalah mahasiswa. Berisi data semua mahasiswa yang ada di elearning. Seperti course, datanya berbentuk tabel. Untuk field yang disimpan adalah NIM dan course yang diambil. 
9. Halaman Jadwal

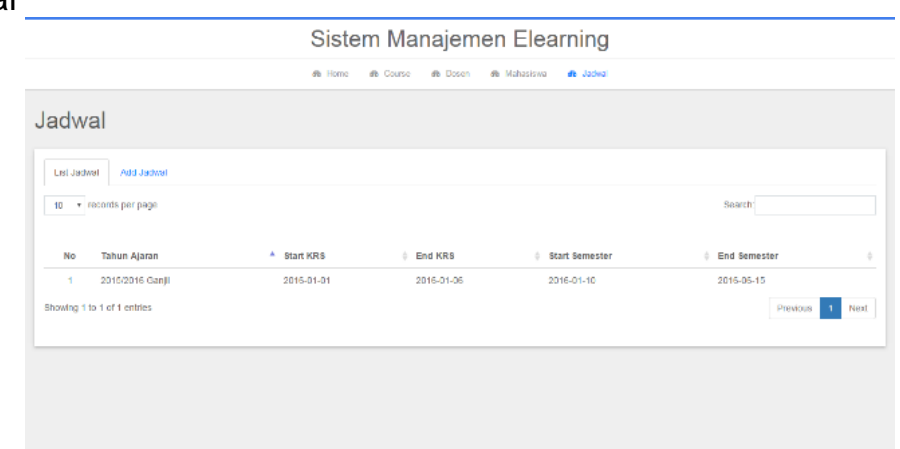

\section{Gambar 16. Tampilan Halaman Jadwal}

Menu terakhir yang utama adalah jadwal. Jadwal yang diinputkan disini nantinya yang akan melakukan trigger terhadap elearning dan SIAKAD. Jadwal yang dipakai untuk melakukan trigger adalah jadwal terakhir.

10. Halaman Input Jadwal

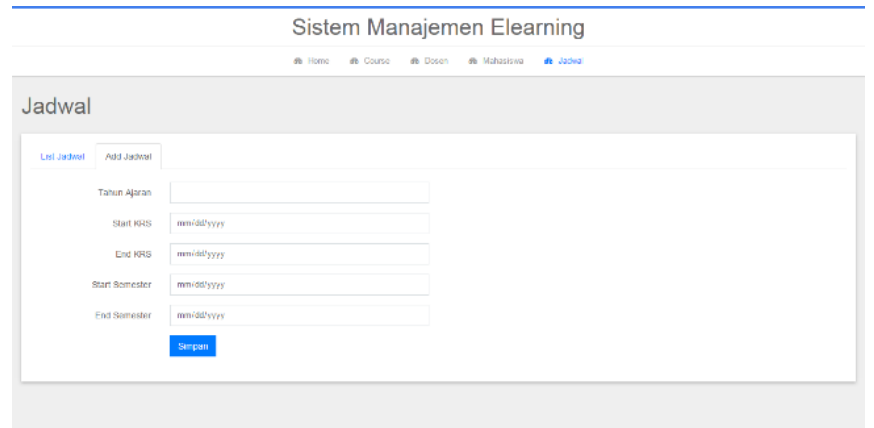

\section{Gambar 17. Tampilan Halaman Jadwal}

Untuk menambahkan jadwal baru, klik add jadwal. Maka akan muncul tampilan form seperti gambar 17. Semua field wajib diisi dan setelah mengklik tombol Simpan, maka akan kembali ke tab list jadwal.

11. Halaman Home Elearning

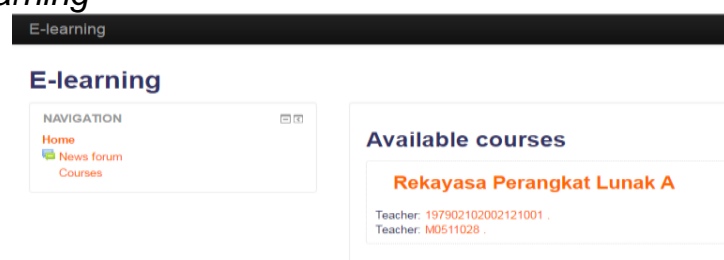

Gambar 18. Tampilan Halaman Home Elearning

Halaman tampilan awal di elearning yang berisi daftar course (kelas) yang sudah dimasukkan dari SIAKAD.

12. Halaman Login Elearning

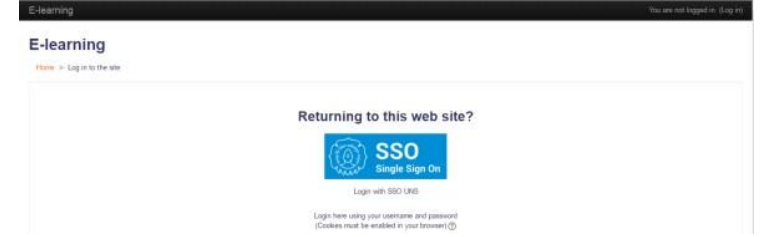

\section{Gambar 19. Tampilan Halaman Login Elearning}

Gambar 19 adalah halaman login elearning. Akan tersedia link untuk login melalui SSO UNS. 
13. Halaman Login SSO

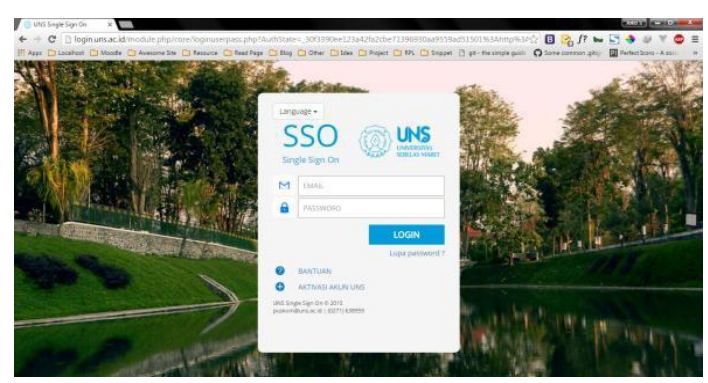

Gambar 20. Tampilan Halaman Login SSO

Setelah link login dengan SSO UNS diklik, maka kita akan di-redirect ke halaman seperti tampak pada gambar 20. Selanjutnya tinggal masukkan email UNS dan password-nya.

14. Halaman Detail Course Mahasiswa

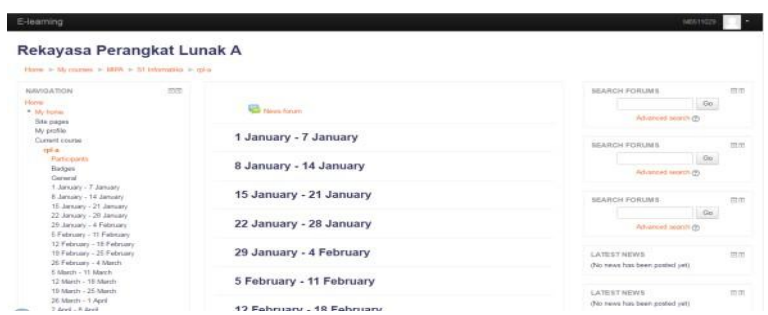

Gambar 21. Tampilan Detail Course Mahasiswa

Ketika sudah login melalui SSO, maka akan di-redirect lagi ke halaman awal elearning. Setelah itu, kita bisa masuk ke dalam course (kelas) yang diambil. Gambar 21 di atas adalah tampilan ketika mahasiswa membuka course yang diambil.

\section{Halaman Detail Course Dosen}

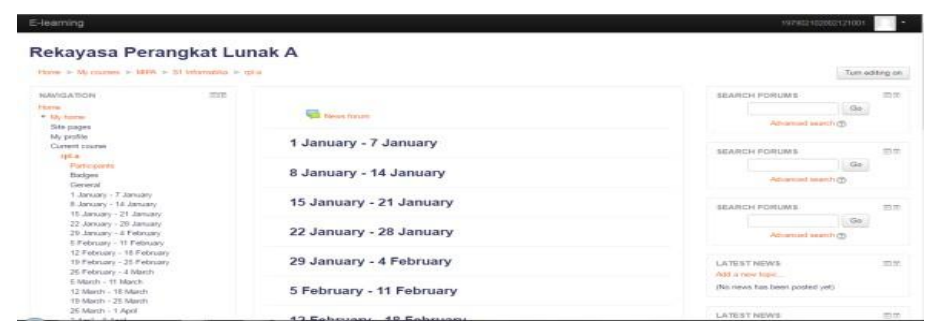

\section{Gambar 22. Tampilan Halaman Detail Course Dosen}

Gambar 22 di atas adalah tampilan dimana yang melakukan login dan membuka course (kelas) adalah seorang dosen. Bedanya adalah dosen bisa melakukan perubahan konten yang ada dikelas.

\subsection{Pengujian}

\subsubsection{Black Box Testing}

Black Box Testing digunakan untuk menguji kebutuhan fungsional apakah sudah sesuai dengan yang diharapkan atau belum. Pengujian dilakukan dengan dua macam scenario, yaitu skenario dengan inputan benar dan scenario dengan inputan yang salah. Hasil dari pengujian black box menunjukkan sistem dapat menjalankan semua fungsional dengan baik 


\subsubsection{Response Time}

Setelah sistem selesai dibuat, dilakukan uji web service untuk response time. Pengujian ini terdiri dari 3 jenis, yang pertama untuk data baru, artinya di elearning (MOODLE) belum ada data, kemudian sistem akan memasukkan data dari SIAKAD dan melakukan enroll terhadap dosen dan mahasiswa. Kedua, unenroll dosen dan mahasiswa terhadap mata kuliah di MOODLE. Dan yang ketiga adalah enroll existing data, artinya data mata kuliah dan user sudah ada di MOODLE setelah dilakukan unenroll, kemudian dilakukan proses enroll lagi. Ketiga pengujian dilakukan masing-masing sebanyak 10 kali. Berikut adalah hasil yang diperoleh dari proses pengujian.

Tabel 6. Pengujian New Data

\begin{tabular}{|l|l|l|}
\hline$\#$ & Timestamp & Waktu Eksekusi (detik) \\
\hline 1 & $2016-04-0420: 10: 50$ & 63,16 \\
\hline 2 & $2016-04-0420: 14: 50$ & 58,86 \\
\hline 3 & $2016-04-0420: 22: 49$ & 58,57 \\
\hline 4 & $2016-04-0420: 27: 17$ & 58,04 \\
\hline 5 & $2016-04-0422: 37: 13$ & 60,77 \\
\hline 6 & $2016-04-0422: 40: 02$ & 65,54 \\
\hline 7 & $2016-04-0422: 42: 33$ & 58,96 \\
\hline 8 & $2016-04-0422: 45: 46$ & 57,47 \\
\hline 9 & $2016-04-0422: 48: 27$ & 60.22 \\
\hline 10 & $2016-04-0422: 52: 03$ & 60,61 \\
\hline \multicolumn{2}{|l|}{ Rata-Rata } & 60,22 \\
\hline
\end{tabular}

Tabel 7. Pengujian Unenroll Data

\begin{tabular}{|l|l|l|}
\hline$\#$ & Timestamp & Waktu Eksekusi (detik) \\
\hline 1 & $2016-04-0423: 06: 26$ & 1,88 \\
\hline 2 & $2016-04-0423: 26: 03$ & 2,29 \\
\hline 3 & $2016-04-0423: 30: 47$ & 1,83 \\
\hline 4 & $2016-04-0423: 31: 24$ & 2,10 \\
\hline 5 & $2016-04-0423: 32: 01$ & 2,16 \\
\hline 6 & $2016-04-0423: 32: 37$ & 2,15 \\
\hline 7 & $2016-04-0423: 33: 15$ & 2,62 \\
\hline 8 & $2016-04-0423: 33: 50$ & 2,55 \\
\hline 9 & $2016-04-0423: 34: 27$ & 1,96 \\
\hline 10 & $2016-04-0423: 35: 24$ & 1,81 \\
\hline \multicolumn{2}{|l|}{ Rata-Rata } & 2,13 \\
\hline
\end{tabular}

Tabel 8. Pengujian enroll existing data

\begin{tabular}{|l|l|l|}
\hline$\#$ & Timestamp & Waktu Eksekusi (detik) \\
\hline 1 & $2016-04-0423: 25: 05$ & 27,84 \\
\hline 2 & $2016-04-0423: 27: 32$ & 35,18 \\
\hline 3 & $2016-04-0423: 31: 18$ & 29,15 \\
\hline 4 & $2016-04-0423: 31: 56$ & 30,43 \\
\hline 5 & $2016-04-0423: 32: 32$ & 28,50 \\
\hline 6 & $2016-04-0423: 33: 09$ & 27,72 \\
\hline 7 & $2016-04-0423: 33: 44$ & 26,65 \\
\hline 8 & $2016-04-0423: 34: 22$ & 26,65 \\
\hline 9 & $2016-04-0423: 34: 58$ & 26,70 \\
\hline 10 & $2016-04-0423: 35: 56$ & 26,16 \\
\hline Rata-Rata & 28,50 \\
\hline
\end{tabular}


Dari data pengujian, didapatkan response time untuk pengujian new data memiliki rata-rata waktu 60,22 detik. Sedangkan, untuk pengujian unenroll data memiliki rata-rata waktu 2,13 detik. Dan untuk pengujian enroll existing data memiliki rata-rata waktu 28,5 detik.

\section{PENUTUP}

\subsection{Kesimpulan}

1. Integrasi dari SIAKAD, E-learning (MOODLE) dan SSO UNS memanfaatkan web service, dapat dilakukan dengan membuat sebuah aplikasi penengah (Bridge App). Aplikasi ini berfungsi sebagai penyesuai data antara SIAKAD dan Elearning.

2. Fungsi web service dari MOODLE, yang digunakan adalah core_course_get_categories, core_course_create_categories, core_course_get_courses, core_course_create_courses, core_user_create_users, enrol_manual_enrol_users, Enam fungsi ini adalah fungsi inti untuk membuat course, melihat daftar course, membuat user, melihat daftar user, melakukan enroll, dan unenroll terhadap user.

3. Rata-rata waktu yang dibutuhkan untuk memasukkan 1 course, 1 dosen, dan 40 mahasiswa adalah 60,22 detik. Sedangkan, waktu yang dibutuhkan untuk unenroll dosen dan mahasiswa adalah 2,13 detik dan untuk enroll jika sudah ada data sebelumnya dibutuhkan waktu 28,5 detik.

\subsection{Saran}

Untuk pengembangan penelitian ini selanjutnya dapat dilakukan penelitian lebih lanjut tentang metode pengarsipan course yang ada pada MOODLE. Pengarsipan course digunakan untuk menyimpan course yang telah digunakan. Hal ini bertujuan agar course yang telah disimpan tersebut dapat dilihat dikemudian hari. Selain itu, perlu dilakukan penerapan system dengan menggunakan SIAKAD yang sebenarnya, sehingga response time yang didapat dapat akan lebih sesuai dengan kondisi yang sebenarnya.

\section{DAFTAR PUSTAKA}

Universitas Sebelas Maret, "Visi, Misi, Tujuan dan Budaya Kerja - Universitas Sebelas Maret," 2015. [Online]. Available: http://uns.ac.id/id/tentang-uns/visi-misi-dan-tujuan/ [Diakses 1 September 2015].

E. H. Darin, "Selling E-Learning, American Society for Training and Development," 2011. Universitas Sebelas Maret, "Elearning UNS," 2015. [Online]. Available: http://elearning.uns.ac.id. [Diakses 20 Desember 2015].

N. Cavus dan T. Zabadi, "A Comparison of Open Source Learning Management Systems," Procedia - Social and Behavioral Sciences, pp. 521-526, 2014.

R. S. Wahono, "Memilih Sistem e-Learning Berbasis Open

Source, RomiSatriaWahono.Net," 2008. [Online]. Available: http://romisatriawahono.net/2008/01/24/memilih-sistem-e-learning-berbasis-opensource/. [Diakses 10 Februari 2016].

The World Wide Web Consortium, "Web Services Architecture," 2015. [Online]. Available: http://www.w3.org/TR/ws-arch/. [Diakses 4 Agustus 2015].

B. Wicaksono, "Pemanfaatan Web Service Moodle Berbasis Rest-Json Untuk Membangun Moodle Online Learning Extension," 2014.

A. Wijayanto, "Implementasi Rest Web Service Dengan Menggunakan Json Pada Aplikasi Mobile Enterprise Resource Planning," 2011.

R. K. Ellis, A Field Guide to Learning Management Systems, Learning Circuits, 2009. 
The World Wide Web Consortium, "Web Services Glossary," 2015. [Online]. Available: http://www.w3.org/TR/ws-gloss/. [Diakses 2 Agustus 2015].

The World Wide Web Consortium, "Web Services Architecture," 2015. [Online]. Available: http://www.w3.org/TR/ws-arch/. [Diakses 4 Agustus 2015].

A. Rodriguez, "RESTful Web services: The basics," 2015. [Online]. Available: http://www.ibm.com/developerworks/webservices/library/ws-restful/. [Diakses 20 Desember 2015].

The World Wide Web Consortium, "Extensible Markup Language (XML)," 2015. [Online]. Available: http://www.w3.org/XML/. [Diakses 6 Agustus 2015].

Json Indonesia, "JSON Tutorial," 2015. [Online]. Available: http://www.w3schools.com/json/. [Diakses 26 Februari 2015].

Json Indonesia, "Pengenalan JSON," 2015. [Online]. Available: http://www.json.org/json-id.html. [Diakses 4 Agustus 2015].

Tech Target, "What is single sign-on (SSO)? - Definition from Whatls.com," 2015. [Online]. Available: http://searchsecurity.techtarget.com/definition/single-sign-on. [Diakses 3 Agustus 2015]. 